\title{
ПРОБЛЕМНІ ПИТАННЯ ЩОДО ПЛАНУВАННЯ ЗЕМЕЛЬ В УМОВАХ ДЕЦЕНТРАЛІЗАЦІЇ
}

Андріяш B. I., д-р наук з держ. упр., доцент, Інститут державного управління, Чорноморський національний університет імені Петра Могили м. Миколаїв, Україна.

Свтушенко О. Н., д-р політ. наук, професор, Чорноморський національний університет імені Петра Могили, м. Миколаїв, Україна.

Лушасіна T. B., канд. політ. наук, старший викладач Чорноморський національний університет імені Петра Могили, м. Миколаїв, Україна.

Лінінська O. A., магістр публічного управління та адміністрування, начальник відділу земельних відносин Воскресенської селищної ради, Вітовського району Миколаївської області, Україна.

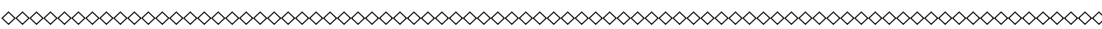

У статті розглядаються теоретичні питання нормативноправового врегулювання земельних взаємовідносин у сфері державного управління. Наголошено, щзо аналіз та оцінка нинішньої правової ситуачії у землекористуванні є свідченням не лише ї̈ надзвичайної гостроти, особливо після прийняття закону про продаж землі, але й про невиріменість багатьох проблем управлінського характеру. Обгрунтовано особливості перспектив практичної реалізачї законодавчих основ земельних взаємовідносин, сформульованих в якості різноманітних актів та програм різного рівня, котрі зіткнулися з изілою низкою проблем в сфері права, управління та самої політики земельної реформи в умовах децентралізації, щзо потребує чіткого встановлення сутності та 
змісту основних понять щзодо земельних взаємовідносин в сфері управління. Досліджуються питання основних форм планування земель об 'єднаних територіальних громад в умовах децентралізаиії. Наголошено, щчо наука державного управління набуває статусу певної продуктивної сили, котра спроможна вносити вагомий вклад у розвиток вітчизняних земельних взаємовідносин ринкового типу, забезпечувати високий рівень ефективності суб'єктів господарювання, консолідувати, інтегрувати та організовувати в управлінському просторі нормативно-правову поведінку всіх учасників земельних відносин.

Ключові слова: земля, земельні ресурси, земельні взаємовідносини, державне управління, державна політика, об'єднані територіальні громади.

Постановка проблеми у загальному вигляді. Декларація «Про державний суверенітет України» поклала початок змін в новітній історії України та стала першим кроком до реформування земельних взаємовідносин, відповідно до якої всі природні ресурси, стали власністю Українською народу, матеріальним фундаментом суверенітету України використання якого має забезпечити матеріальні й духовні потреби громадян. Це започаткувало процес створення нової системи, що суттєво різниться від старої системи, впровадженої у галузі земельних відносин минулих років, яка грунтувалася 3 урахуванням інтересів держави як монополіста, щодо права володіння земельним потенціалом. В даній системі не було враховано економічні інтереси пересічного громадянина, мотивації його праці, а зрештою ефективності суспільного виробництва. Приватна власність на землю в незалежно від країни стимулює іiі економічне зростання, а саме: створює нові умови доступу до землі як капіталу, земля є основним багатством держави, і як наслідок, іiї вартість постійно зростає, чітко відображено зв'язок з економічною діяльністю; по-друге, приватна власність $€$ фактором підвищення рівня надійності, поліпшення умов для управління та існування, заохочення створення нових підприємств та залучення прямих інвестицій. 
Основні аспекти формування земельних взаємовідносин закладені «Земельним Кодексом України» (далі - ЗКУ), який набув чинності 1 січня 2002 р., а також знайшли своє місце у низькі законів, серед яких: Закон України «Про охорону земель» (далі закон № 962-IV), оскільки продаж прав на користування землею також підпадає під дію даного закону, всі користувачі несуть повну відповідальність перед власником за недопущення погіршення стану об’єкту використання, Закон України «Про землеустрій» (далі закон № 858-IV), яким закріплено процедури визначення земельної ділянки як об'єкта правових відносин в Україні, Закон України «Про державну реєстрацію речових прав на нерухоме майно та їх обмежень» (далі закон № 1952-IV), згідно даного акту, має бути доступ у вільній формі до відомостей щодо власника майна, а також право вчинення будь яких дій відносно ресурсу починається 3 моменту реєстрації права власності, Закон України «Про оцінку земель», яким закріплені правила визначення вартості об’єкта в грошовому еквіваленті для оформлення договірних відносин або зміну власника на підставі купівлі-продажу; Закон України «Про державну експертизу землевпорядної документації», що регламентує відповідність проектної документації вимогам держави; Закон України «Про державний контроль за використанням та охороною земель», що має на меті визначення правил користування природними ресурсами; Закон України «Про внесення змін до деяких законодавчих актів України щодо розмежування земель державної та комунальної власності» (далі закон № 5245-VI), який чітко визначав розпорядників землі відповідно до категорії та прав на неї; деякими іншими законодавчими актами.

Аналіз останніх досліджень i публікацій. У зв'язку із розвитком сучасних наук в різних галузях законодавства, а саме: містобудівного, земельного, екологічного, аграрного права України було розпочато дослідження різних аспектів планування земель $\mathrm{i}$ територій як на місцевому, регіональному та національному рівнях. Проблемам теорії та практики земельних ресурсів та планування земель на рівні територіальних громад займались сучасні вітчизняні й зарубіжні вчені, такі як: Н. Красков, А. Велікандо, Д. Воронков, 
В. Носік та ін. Окремі аспекти розмежування повноважень в галузі використання земель між органами місцевого самоврядування й органами державної влади були предметом вивчення таких дослідників, як: В. Андріяш, О. Свтушенко, В. Смельянов, А. Ібрагімова, О. Малікіна тощо.

Розглядаючи стан наукової розробки питання щодо правових форм планування земель, варто зазначити, що у сучасних наукових колах дослідників цієї галузі небагато, але чітко простежується тенденція підвищення інтересу до цієї проблематики.

Метою статті є проаналізувати проблемні питання щодо правових форм планування земель об'єднаних територіальних громад в умовах децентралізації.

Формулювання цілей статті (постановка завдання). В процесі дослідження були поставлені наступні завдання:

$\checkmark$ розглянути особливості нормативно-правових основ регулювання земельних взаємовідносин;

$\checkmark$ визначити особливості правових форм планування земель в умовах децентралізації;

$\checkmark$ окреслити перспективи формування ефективних правових форм планування земель на рівні ОТГ.

Виклад основного матеріалу дослідження. Одним 3 головних документів в галузі земельних взаємовідносин є Закон № 5245VI, мета якого полягала у «визначенні повноважень, пов’язаних 3 землями сільськогосподарського призначення, між різними розпорядниками земель, залежно від категорії та права власності» [13]. В даному випадку землі сільгоспугідь державної власності відійшли до Головного Управління Держгеокадастру.

Хочеться зазначити що саме в цей період виникає твердження про «мовчазну згоду». Структурними підрозділами головного управління Держгеокадастру направлялися офіційні листи до відповідних рад (в залежності від місця розташування земельних ділянок) з метою отримання позиції щодо передачі земельної ділянки у приватну власність певному громадянину України, із визначенням кінцевого терміну надання відповіді строком в 10 днів. Якщо така відповідь не надходила у встановлений строк, така земельна ділянка 
передавалася громадянину за мовчазною згодою. Дуже часто органи місцевого самоврядування (далі ОМС) отримували ці листи після стікання кінцевого терміну. Тобто земельні ділянки передавались у власність без згоди ради, а лише повідомлялись про факт передачі земельної ділянки у власність певному громадянину. Що в свою чергу, призвело до обмеження ролі ОМС, щодо «регулювання процесу відведення землі у приватну власність із земель резервного фонду держави та позбавило можливості здійснювати функцію контролю щодо сплати земельного податку новими власниками земельних ділянок» $[17$, с. 25]. Все це негативно відображається у «процесі наповнення місцевих бюджетів та призводить до недоотримання податків та зниження рівня економічної спроможності громади» [2].

Проводячи аналіз наведених норм глави 30 ЗКУ, який присвячено «Планування використання земель», а також деяких інших норм законодавства в галузі земельних питань дозволяє виокремити наступні форми щодо планування земель, як:

- розробка програм направлених на використання земель та відповідно їх охорони;

- обговорення і затвердження вищезазначених програм;

- природно-сільськогосподарське районування;

- визначення норм «щодо використання земель, які розташовані в межах населених пунктів, з урахуванням зонування територій населених пунктів, селищ» [19].

3 метою отримання підтвердження вищенаведеного, пропонуємо розглянути позиції п. 5 ст. 20 ЗКУ, до компетенції якої відносяться види використання певних категорій земельних ділянок (виключенням $\epsilon$ землі «сільськогосподарського призначення та землі оборони»), отже використання землі «визначаються власником або користувачем одноосібно з урахуванням вимог, встановлених законодавчими актами щодо шляхів користування певної категорії земель, а також урахуванням розробленої і затвердженої містобудівної документації та документації із землеустрою» [19].

Враховуючи направленість діїЗакону України «Про землеустрій» шляхи «використання земельної ділянки визначають іiі цільове призначення та охорону даного виду угідь», тобто відповідно 
до законів «земельну ділянку треба використовувати лише за призначенням, яке визначається у відповідності із розробленою документацією із землеустрою» [15].

В ЗКУ ст. 39 чітко окреслила позицію щодо необхідності «використання земель житлової або громадської забудови відповідно до затвердженого генерального плану населеного пункту, плану зонування території, плану земельно-господарського устрою, 3 обов'язковою умовою дотриманням будівельних норм, державних стандартів і норм» [19].

Порядок розробки, затвердження і використання містобудівної документації як правових» форм планування територій i використання земель у межах населених пунктів» визначені у Законі України «Про регулювання містобудівної діяльності» від 17 лютого 2011 року [7].

У своїх зауваженнях, відносно аналізу норм земельного законодавства України, В. Носік, запропонував виділити «дві форми планування території України, розглядаючи землю, як об’ єкт використання-сільськогосподарського чи несільськогосподарського призначення, а саме: природно-сільськогосподарське районування сільськогосподарських угідь і зонінг території населених пунктів» [6, с. 349-350]. Саме такий поділ землі впроваджено у Воскресенській селищній раді.

3 метою всебічного розкриття поставленого питання, та для ознайомлення із громадою, пропонуємо розглянути коротку характеристику Воскресенської ОТГ Вітовського району Миколаївської області.

У грудні 2016 року процес децентралізації та волевиявлення мешканців зацікавлених громад призвів до появи ВоскресенськоїОТГ, до складу якої увійшли Воскресенська селищна рада, Калинівська сільська ради та Пересадівська сільська рада. Об'єднання відбувалося у відповідності до Закону України «Про добровільне об'єднання територіальних громад» [9] на I сесії 8 скликання було прийнято рішення № 6 «Про утворення Воскресенської селищної ради».

До складу громади увійшли населені пункти: смт. Воскресенське, села Пересадівка, Калинівка та селище Горохівка з адміністративним 
центром у смт. Воскресенське Вітовського району Миколаївської області. На рис. 1 представлено загальну територію громади та іiі географічне розташування.

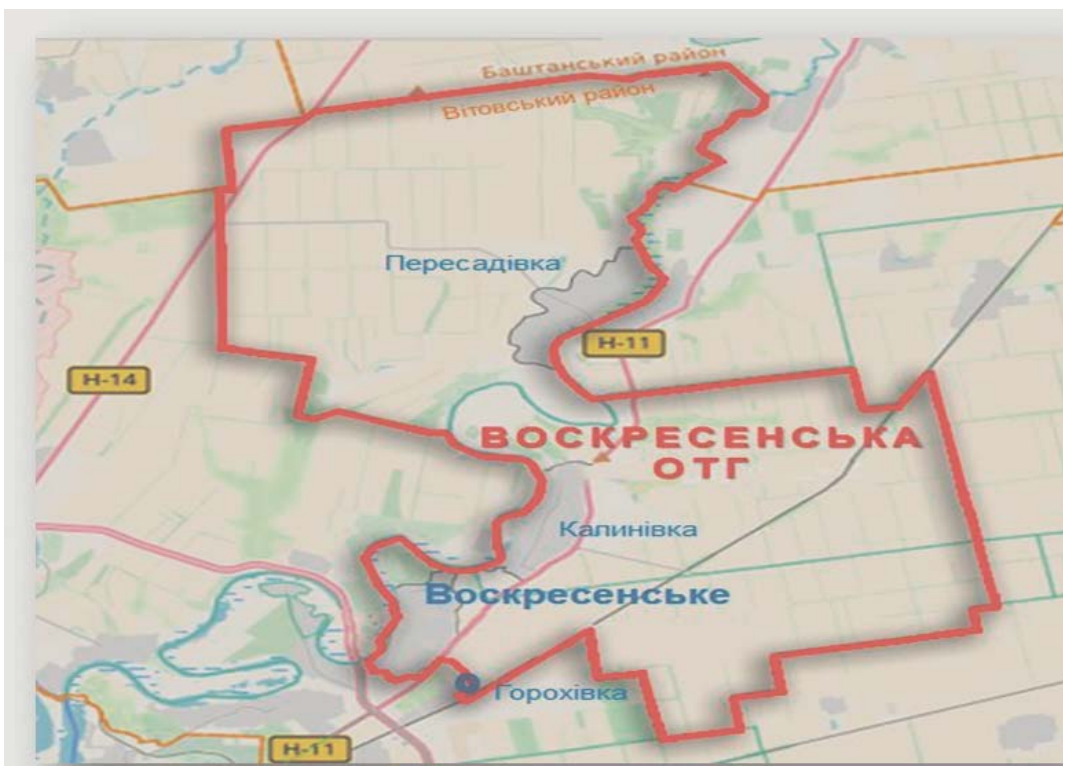

Puc. 1.Територія Воскресенської ОТГ

Варто звернути вашу увагу на те, що село Пересадівка ніби відокремлене від інших населених пунктів громади, оскільки не існує чіткого сполучення через землі, що входили до складу колишніх рад. Натомість населені пункти Пересадівка та Калинівка «сполучаються між собою через водне дзеркало річки Інгул» [5, с. 23-24].

Тобто ці дві адміністративно територіальні одиниці межують між собою по береговій смузі, що є досить незвичним відповідно до традиційного поняття розмежування територій.

Загальна площа ОТГ - 19239,996 га, площа населених пунктів становить 1306,964 га (рис. 2). 


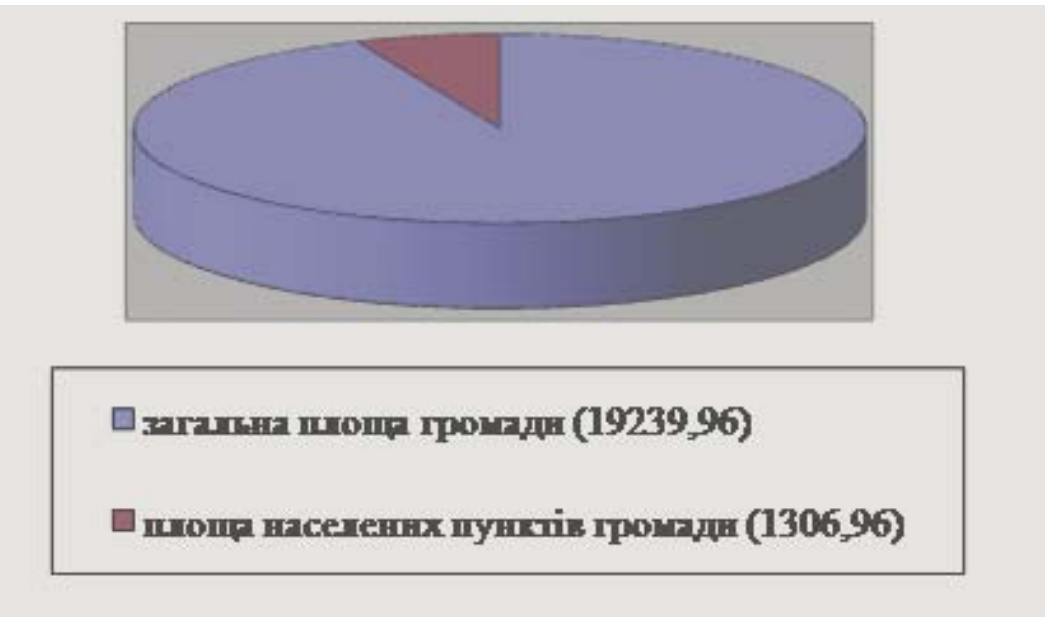

Puc. 2. Розподіл земель Воскресенської ОТГ в межах і за межами населених пунктів.

Отже із наведеного вище чітко розуміємо що під час об'єднання у повноваженнях ОМС, із загальної кількості земель селищної ради, перебуває лише 6,8 \% (землі населених пунктів). Це звісно $\epsilon$ «крихти». Саме 3 цього моменту було прийнято рішення про проведено моніторингу щодо реальних можливостей громади та перспектив на майбутній рік.

На земельний відділ поклали повноваження, з питань визначення інвестиційне привабливих земельних ділянок для інвесторів. На даному етапі селищна рада стикнулася з проблемою «зв’ язаних рук». Ст. 24 Закону України «Про регулювання містобудівної діяльності» обмежила законні права органів місцевого самоврядування, в частині розпорядження землями комунальної власності, а саме: «заборона відчуження земельних ділянок ( передача в оренду, укладання угоди купівлі-продажу або безоплатна приватизація), при відсутності зонінгу території населеного пункту або детального плану частини земельної ділянки» [12]. Колегіально було прийнято рішеннями селищної ради про надання дозволу на розробку генеральних планів із планами зонування населених пунктів Воскресенської селищної ради. 
3 метою врахування потреб всіх верст населення та формування інвестиційноїпривабливостігромади, було зібрано та проаналізовано данні протягом останніх 3-х років:

- відносно зміни кількісного складу населення з урахування статі та віку;

- сучасний стан забезпечення населення земельними ділянками, з урахування можливої перспективи щодо зміни меж адміністративно територіальних утворень;

- проаналізовано існуючі об'єкти комунального господарства;

- враховано вимоги щодо визначення та врахування державних та регіональних інтересів.

Додатково будо проаналізовано розподіл працюючих за видами діяльності (рис. 3).

Найбільша частка працюючих зайнята в наступних галузях:

сільське господарство - 28\%,

будівництво - 22\%,

промисловість - 19\%,

оптова та роздрібна торгівля, ремонт автотранспортних засобів $-12 \%$,

незначну частку займають таки види діяльності, як: транспортне господарство, складське господарство, поштова та кар'єрна діяльність, організація харчування, фінансова та страхова діяльність тощо.

Отже, пріоритетними видом діяльності Воскресенської громади $\epsilon$ сільгоспвиробництво та промисловість, а для розвитку даних галузей виробництва потрібні земельні ресурси.

3 метою задоволення потреб промислової галузі, при проходженні процедури громадського обговорення, було прийнято рішення ввести у склад селища Горохівка промислову зону, з метою збільшення економічної спроможності громади, та збільшити площу смт. Воскресенське для задоволення містобудівних потреб.

Законом України «Про регулювання містобудівної діяльності» передбачено розроблення містобудівної документації, яка «визначає умови та обмеження використання території населених пунктів» [12]. 


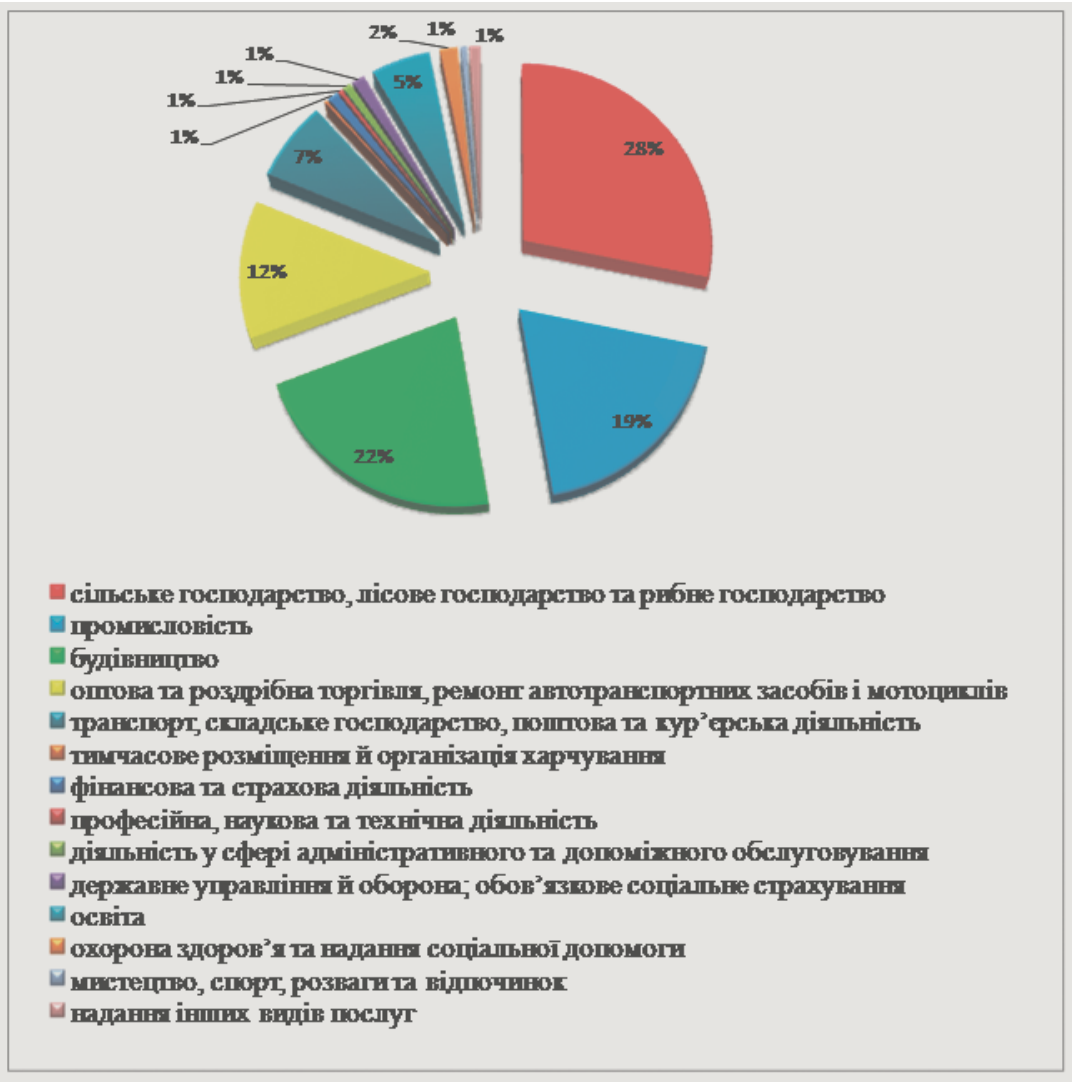

Puc. 3. Розподіл працюючих за видами діяльності.

В основу функціонального зонування території населених пунктів громади покладені такі «основні принципи містобудування:

$\checkmark$ дотримання чіткості функціональних зон та їх раціональне взаєморозміщення;

$\checkmark$ формування планувального каркасу, спрямованого на забезпечення мінімізації витрат часу на пересування населення між місцями розселення, прикладення праці, установами громадського обслуговування; 
$\checkmark \quad$ створення архітектурно-планувальної структури, що забезпечує виразне об'ємно-просторове рішення житлової та громадської забудови;

$\checkmark$ охорона навколишнього середовища шляхом реалізації містобудівних та інженерних заходів;

$\checkmark$ забезпечення екологічного балансу природноландшафтних та урбанізованих територій» [1].

3 метою створення раціональної планувальної структури передбачається зонування території населених пунктів громади 3 виділенням таких функціональних зон за «видами переважного використання:

$>\quad$ громадські: $Г, \Gamma-1, \Gamma-2, \Gamma-3, \Gamma-4, \Gamma-5,, \Gamma-6$;

$>\quad$ житлові: Ж-1, Ж-3, ПЖ-1;

$>$ виробничі:В-6, В-5, В-2, В-1;

$>$ меморіальна С-2.

$>$ рекреаційна зона: Р-3;

$>$ спеціальна зона зелених насаджень в санітарно-захисних зонах: C-3;

> $\quad$ зона сільськогосподарського призначення: CB-1, CB-2;

> $\quad$ зони транспортної інфраструктури: ТР-2;

$>\quad$ комунально-складська зона: КС-3-1, КС-4-1, КС-5;

$>\quad$ зона земель історико-культурного призначення - IК» [4, c. 23].

Також селищною радою було враховано місце розташування громади, а саме: Воскресенська ОТГ розташована в приміській зоні м. Миколаєва в напрямку автошляху Миколаїв - Новий Буг на відстані 15 км від міста. На відстані 3 км від селища знаходиться залізнична станція Горохівка (лінія Миколаїв - Сортувальний Долинська).

Територія громади межує:

- $\quad$ на півночі - 3 Інгульською сільською радою Баштанського району, Михайло-Ларинською сільською радою Вітовського району;

- на сході - Грейгівська селищна рада Вітовського району, Первомайська селищна рада Вітовського району;

- на заході - Каравелівська сільська рада Вітовського району; 
- $\quad$ на півдні з Шевченківською ОТГ та Мішково-Погорілівська сільська рада Вітовського району Миколаївської області.

Таке межування ОТГ носить інвестиційний привабливий характер для даних територій.

Якщо розглядати населення громади, що становить 12350 мешканців, з них: чоловіки - 6106 осіб, жінки - 6244 осіб.

В табл. 1. та рис. 4, подано розподіл мешканців за населеними пунктами громади, а також відстань від центру громади до цих населених пунктів.

Таблиия 1

\section{Населені пункти Воскресенської ОТГ та їх характеристики}

\begin{tabular}{|c|c|c|c|}
\hline $\begin{array}{l}\text { № } \\
\text { П/ா }\end{array}$ & \begin{tabular}{|c} 
Найменування \\
територіальних громад \\
та населених пунктів, \\
що входять до їх \\
складу, із зазначенням \\
адміністративного статусу
\end{tabular} & $\begin{array}{c}\text { Чисельність } \\
\text { населення } \\
\text { станом на } \\
01.01 .2020\end{array}$ & $\begin{array}{c}\text { Відстань до } \\
\text { адміністративного } \\
\text { центру громади, } \\
\text { км }\end{array}$ \\
\hline & \multicolumn{3}{|c|}{ Воскресенська селищна рада } \\
\hline 1 & смт. Воскресенське & 5100 & - \\
\hline 2 & с. Пересадівка & 3490 & 8 \\
\hline 3 & с. Калинівка & 3515 & 3 \\
\hline 4 & с-ще Горохівка & 268 & 1 \\
\hline
\end{tabular}

Нами було зроблено висновки про досить високий рівень забезпеченості трудовими ресурсами, що збільшує шанси на залучення іноземних інвесторів.

I якщо провести порівняльний аналіз площ та щільності населення в межах Воскресенської громади та відповідно Вітовського району і Миколаївської області в (табл. 2) чітко видно, що це $є$ досить вагомі данні з урахуванням того що місто Миколаїв $є$ містом обласного значення. Воскресенська селищна рада, з урахуванням досить невеликого земельного ресурсу володіє, досить високими показниками трудового ресурсу. Що вказує на необхідність «створення нових робочих місць, а це можливо лише 
при будівництві підприємств, для чого необхідно раціонально використовувати землю» [8].

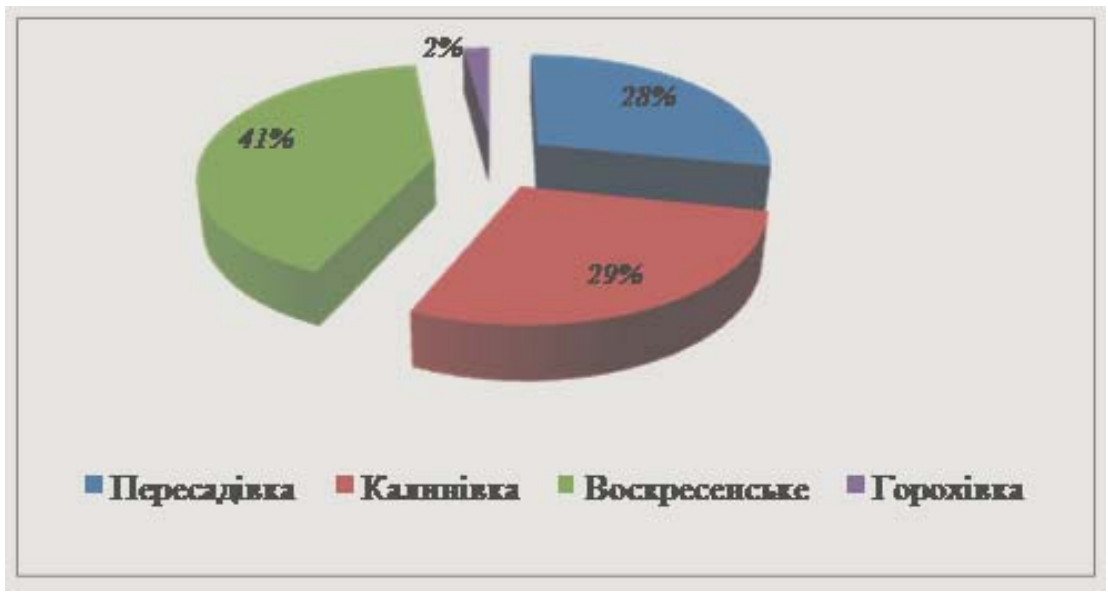

Puc. 4. Розподіл мешканців між населеними пунктами громади

Таблиия 2.

\section{Порівняння таблиця площ та кількості населення}

\begin{tabular}{|c|c|c|c|c|c|}
\hline Регіони & $\begin{array}{c}\text { Площа, } \\
\text { км2 }\end{array}$ & $\begin{array}{c}\text { Площа у \%агальної } \\
\text { площі/ } \\
\text { району/ } \\
\text { області }\end{array}$ & $\begin{array}{c}\text { Насе- } \\
\text { лення }\end{array}$ & $\begin{array}{c}\text { Насе- } \\
\text { уення } \\
\text { загаль- } \\
\text { ного } \\
\text { насе- } \\
\text { лення/ } \\
\text { області }\end{array}$ & $\begin{array}{c}\text { Густота } \\
\text { насе- } \\
\text { лення }\end{array}$ \\
\hline $\begin{array}{c}\text { Воскресен- } \\
\text { ська } \\
\text { громада }\end{array}$ & 192,39 & - & 12350 & - & 64,299 \\
\hline $\begin{array}{c}\text { Вітовський } \\
\text { район }\end{array}$ & 1460,00 & 13,18 & 50110 & 24,65 & 34,32 \\
\hline $\begin{array}{c}\text { Миколаїв- } \\
\text { ська область }\end{array}$ & 24598,00 & 0,78 & 1150 & 1,07 & 46,8 \\
\hline
\end{tabular}


Якщо розглянути землі сільськогосподарського призначення то, земельний фонд Воскресенської ОТГ становить 19239,996 га, 3 яких 16673,7 га займають сільськогосподарські землі:

> 253,76 га - багаторічні;

> 14754,03 га - рілля;

> 1664,57 га - землі пасовищ та сінокосів;

> 21,34-землі водного господарства;

$>$ 1306,966 - забудова;

$>1259,33$ - інші.

Більш чітко розподіл земель за сільськогосподарськими угіддями показано на рис 5. відповідно до якої земельні угіддя зазначені у відсотковому співвідношенні до загальної площі громади.

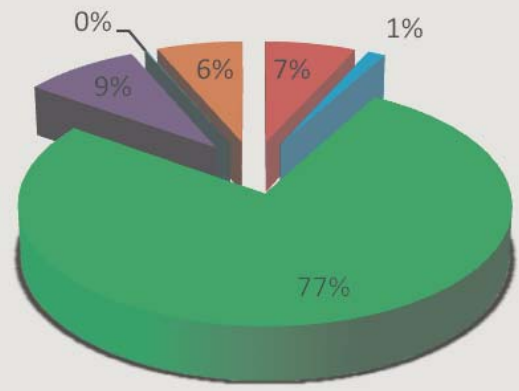

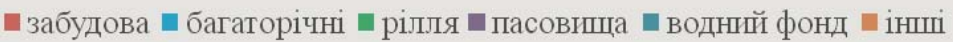

Puc. 5. Розподіл земельного фонду за видами земельних ресурсів

Таким чином питома вага земель Воскресенської селищної ради представлена ріллею. Ріллі - це орні землі, категорія яка використовується для систематичного розрахування та вирощування сільськогосподарських культур. На таких ділянках забороняється будівництво об'єктів нерухомого майна, засадження 
багаторічними деревами та випасання худоби. Більша їх частина перебуває в приватній власності громадян та підпадає під мораторій, щодо продажу, оскільки використовується для товарного сільськогосподарського виробництва та є пайовою землею.

На наступній щаблині розміщені землі пасовищ, які використовуються для сінокосіння та випасання худоби. Дана категорія є менш ціною відповідно до якості грунтів. Хочеться зауважити що на сучасному етапі розвитку, землі пасовищ активно використовуються для вирощування культур.

Положення статті 37 Закону України «Про охорону земель», встановлює основні вимоги щодо охорони родючості грунтів, відтак:

«ч. 1 - Власники та землекористувачі, в тому числі орендарі, земельних ділянок зобов'язані здійснювати заходи щодо охорони родючості грунтів».

«ч. 2 - Використання земельних ділянок способами, що призводять до погіршення їх якості, забороняється».

«ч. 3 - На землях сільськогосподарського призначення може бути обмежена діяльність щодо: ...розорювання сіножатей, пасовищ» [10].

Отже, діюче законодавство чітко дає зрозуміти, що вказані види сільськогосподарських угідь можуть використовуватися виключно для викошування сіна або для випасання худоби відповідно. А власники таких земель не лише порушують вимоги законів а й отримують більш високі прибутки за вирощену продукцію хоча сплачують значно менші податки. Що є проявом тіньової економіки. Плата за землю нараховується відповідно до нормативної грошової оцінки ділянки, землі пасовищ мають більш знижену оцінку.

Органи місцевого самоврядування знайшли шляхи вирішення цієї проблеми. Відповідно до Постанови КМУ № 482 від 22.07.2016 «Про внесення змін до деяких постанов Кабінету Міністрів України» було змінено Положення про Державну службу з питань геодезії, картографії та кадастру і визначено, що «центральним органом виконавчої влади, що забезпечує та реалізує політику держави у сфері контролю (наглядова функція) в агропромисловому комплексі, щодо дотримання земельного законодавства, відносно використання 
земельного потенціалу, як окремої одиниці, з урахуванням категорії, призначення та відповідно і охорони земельних ресурсів будьякої форми власності (державна, приватна чи комунальна)» [13]. Особливий наголос в даному випадку ставлять на родючість грунтів.

Якщо розглядати повноваження вищезазначеного органу в частині охорони земельного ресурсу, то:

$\checkmark$ землекористування в країні має бути «раціональним та обгрунтованим, діяльність контролюючих органів направлена на визначення порушників та притягнення їх до відповідальності» [3];

$\checkmark \quad$ чітке визначення необхідності існування таких категорій сільгоспугідь як, землі вкриті чагарниками або лісових земель та захист їх від процедури вилучення 3 метою задоволення інших потреб без належного обгрунтування і визначення, як суспільно необхідної потреби;

$\checkmark \quad$ розробка «програм щодо захисту земель від природних явищ: ерозії, селів, підтоплення, заболочування, вторинного засолення, переосушення, ущільнення, забруднення відходами виробництва, хімічними, радіоактивними речовинами та від інших несприятливих природних і техногенних процесів» [7];

$\checkmark$ необхідність збереження заболочених земель, як окремих одиниць;

$\checkmark \quad$ недопущення погіршення зовнішнього стану ландшафтів, що виникли, як результат діяльності людства 3 урахуванням їх екологічної;

Все вищеперераховане дає нам можливість усвідомити, що порушення законодавства тягне за собою відповідальність. Як ми бачимо створено спеціалізоване управління, яке контролює процес використання земель України. Все ще змушує землекористувачів дбати про стан майна що використовується, збереження його природних якостей.

Особливу увагу необхідно приділити такій категорії земель, як забудовані землі. До цієї категорії відносяться території населених пунктів, землі, які використовуються для обслуговування сільськогосподарського виробництва, вони визначені як землі під сільськогосподарськими будівлями i дворами, а також під 
господарськими шляхами i прогонами, i ті, що тимчасово не використовуються у виробництві сільськогосподарської продукції або використовуються з обмеженнями.

Отже починаючи із набрання чинності Розпорядження КМУ від 31.01.2018 року № 60-р Держгеокадастру було «надано повноваження про проведення інвентаризації сільськогосподарських земель, які перебувають у власності держави, а саме: рілля, забудовані землі та пасовища» [16].

Наказом державної служби 3 питань геодезії, картографії та кадастру № 45 від 15.03.2018 року було розпочато процес інвентаризації на територіях ОТГ [11]. Відповідно до даного нормативного документу, було визначено виконавця послуг, щодо формування земельних ділянок та внесення відповідних даних до Державного земельного кадастру України. Ним визначено державне підприємство «Центр державного земельного кадастру», 3 яким було укладено відповідний договір.

Процес проведення інвентаризації $є$ досить складний та довготривалий, за для скорочення термінів були залучені фахівці селищної ради. Земельним відділом було підготовлено графічні матеріали щодо земельних ділянок, які потрібно включити до стиску земель що формуються.

Після проведення вищезазначених процедур в адміністративних межах Воскресенської селищної ради було сформовано 45 земельних ділянок на загальну площу 1624,0899 га. Серед яких: пасовища 505,9012 га., забудовані землі (під господарськими будівлями i дворами) - 62,4872 га., рілля - 1055,6907 га (рис. 6).

Отже при формуванні розподілу, згідно виду земельних угідь, ми бачимо, що питому вагу займає саме богарна рілля, яка має найвищу цінність, оскільки нормативна грошова оцінка 1 га. ріллі по Миколаївські області складає - 27038 грн., пасовищ - 5239 грн., забудовані землі - 26000 грн.

Наступним кроком для громади став наказ ГУ Держгеокадастру у Миколаївській області №3563/0/14-18-СГ від 05.06.2018 року разом із актом приймання-передачі земельних ділянок сільськогосподарського призначення державної власності у 
комунальну Воскресенської селищної ради Вітовського району Миколаївської області від 06.06.2019 року.

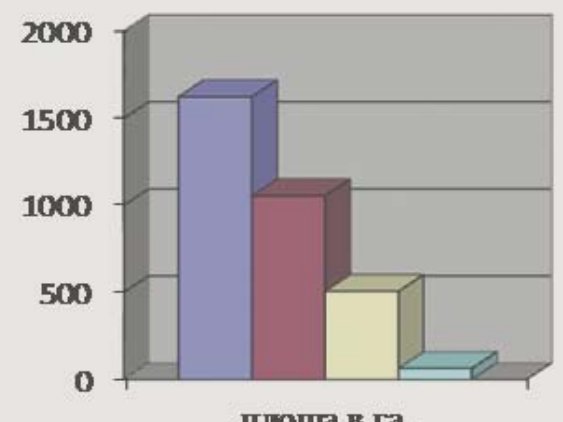

ппоща в га.

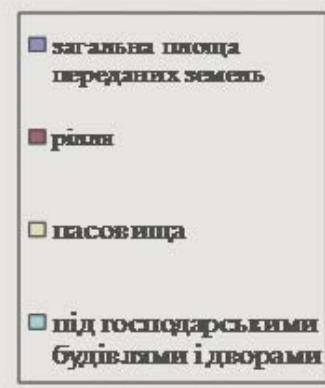

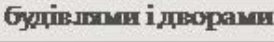

Puc. 6. Розподіл землі за видами земельних угідь.

Відповідно до цього наказу рада отримала інформацію стосовно умов використання та обмеження (обтяження) щодо використання кожної земельної ділянки. Додатково було надано вичерпну інформації щодо користувачів земельних ділянок та відповідно переліки документів, які підтверджують право користування землею.

На підставі вищенаведеного можна зробити висновки що додатковий ресурс, який отримала селищна рада $є$ досить великим у порівнянні із землями в межах населених пунктів, що у сукупності своїй є великим потенціалом розвитку громади [18, с. 26-27].

Висновки. На нашу думку будь який розподіл землі в адміністративних межах громади завжди поділяється на сільськогосподарське районування та зонування території селищ. Якщо розглядати територію всієї Воскресенської ОТГ, то на 80\% вона складається із земель сільськогосподарського призначення, яке в свою чергу має певні види використання в залежності від якісного складу грунтів та цільового призначення. Земельне законодавство чітко регламентує правила використання цих земель та зазначає відповідальність за їх порушення. Розкладаючи викладене на 
певні аспекти, напрошується загальний висновок про те, що децентралізація влади, яка запроваджена в Україні та дерегуляція бізнесу стимулює зміни в усіх сферах життєдіяльності сільських, селищних, міських громад, що перебувають в стадії об'єднання в єдині територіальні громади.

Аналіз законодавства щодо планування земель і територій показує, різницю правовідносин щодо формування, затвердження i застосування містобудівної документації на тлі правового регулювання земельних відноси. Причому упускають питання врахування потреб та інтересів новостворених адміністративних одиниць, об'єднаних територіальних громада як нових суб'єктів права комунальної власності на землю. На теперішньому етапі розвитку необхідно розробити і законодавчо обгрунтувати єдину правову форму планування земель ОТГ, яка має забезпечувати функціональне використання та охорона земель усіх форм власності на землю на основі просторового планування територій.

Проаналізувавши права та повноваження Воскресенської ОТГ можемо стверджувати, що законодавча база поступово змінюється у бік захисту прав та законних інтересів громад. Держава намагається створити конкурентоспроможні одиниці, які самостійно зможуть не лише існувати але і розвиватись, посилюючи свої позиції, як власники найціннішого ресурсу. Громади на теперішньому етапі лише навчаються використовувати надані можливості. Перші спроби нерішучі та отримані шляхом проб та помилок. Але позитивний розвиток вже чітко спостерігається. Громада розуміє що iii економічна стабільність залежить в першу чергу від раціонального використання всього наявного ресурсу.

Законодавча база ще неврегульована повністю, залишаються відкритими питання зміни неефективних землекористувачів користувачів. Та потрібна працювати 3 підприємствами, які знаходяться фактично на території, але зареєстровані в місцях. Наразі піднімаються питання щодо сплати податків за місцем безпосереднього здійснення господарської діяльності.

Це лише перші кроки, але вони є вже суттєвими та направлені на реалізацію владних повноважень громад для створення економічно 
потужної та розвиненої громади, яка здатна забезпечити не лише потреби свого населення, але і підготувати фундамент для нащадків.

\section{Стаття надійшла до редакції: 23.01.21}

\section{PROBLEM ISSUES REGARDING LAND PLANNING IN CONDITIONS OF DECENTRALIZATION}

Victoria Andriyash, Doctor of Science in Public Administration, Associate Professor of the Department of Public Administration and Administration Institute of Public Administration Black Sea National University of Petro Mohyla Mykolaiv, Ukraine.

Alexander Evtushenko, Doctor of Political sciences, professor Black Sea National University of Petro Mohyla, Mykolaiv, Ukraine.

Tetyana Lushahina, Candidate of Political Science, Senior Lecturer, Department of Political Science, Black Sea National University of Petro Mohyla, Mykolaiv, Ukraine.

Oksana Lininska Master of Public Administration Head of the Department of Land Voskresenska village council, Mykolaiv region, Ukraine.

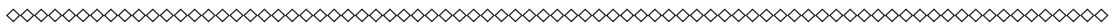

The article considers theoretical issues of regulatory and legal regulation of land relations in the field of public administration. It is emphasized that the analysis and assessment of the current legal situation in land use is evidence not only of its extreme severity, especially after the adoption of the law on land sales, but also of the unresolved many problems of an administrative nature.

The peculiarities of the prospects of practical implementation of the legislative framework of land relations, formulated as various acts and programs of different levels, which face a number of problems in the field of law, governance and land reform policy in decentralization, which requires a clear definition of the essence and content of basic concepts. land relations in the field of management. 
The issues of the main forms of land planning of united territorial communities in the conditions of decentralization are studied. It is emphasized that the science of public administration acquires the status of a productive force that can make a significant contribution to the development of domestic land relations of the market type, ensure a high level of efficiency of economic entities, consolidate, integrate and organize regulatory behavior of all participants in land relations.

Decomposing the above into certain aspects, the general conclusion is that the decentralization of power introduced in Ukraine and deregulation of business stimulates changes in all spheres of life of rural, urban, urban communities, which are in the process of unification into a single territorial community.

Analysis of the legislation on land and territory planning shows the difference in legal relations for the formation, approval and application of urban planning documentation against the background of legal regulation of land relations. And they miss the issue of taking into account the needs and interests of the newly created administrative units, united territorial communities as new subjects of communal land ownership.

Keywords: land, landresources, land relations, public administration, public policy, united territorial communities.

\section{Received: 23.01.21}

\section{References}

1. Andriiash V. I., Malikina O. A., Bizikova T.V. (2016) Uchast hromadskosti $\mathrm{v}$ protsesakh terytorialnoho planuvannia i rozvytku [Public participation in the processes of spatial planning and development] Naukovi pratsi [Chornomorskoho derzhavnoho universytetu imeni Petra Mohyly kompleksu "Kyievo-Mohylianska akademiia"]. Seriia : Derzhavne upravlinnia. T. 267. Vyp. 255. Retrieved from http: nbuv.gov.ua/UJRN/Npchdu_2016_267_255_3 [in Ukrainian]

2. Biudzhetnyi kodeks Ukrainy (2010) Zakon Ukrainy № 2456-VI vid 8 lypnia 2010 roku [Budget Code of Ukraine] Ofitsiinyi Sait Verkhovnoi Rady Ukrainy. Retrieved from http: https://zakon.rada.gov.ua [in Ukrainian] 
3. Derzhavna prohrama staloho rozvytku silskoho rozvytku silskykh terytorii na period do 2020 roku (2010) [State program of sustainable development of rural development of rural areas for the period up to 2020] Rozporiadzhennia Kabinetu Ministriv Ukrainy vid 3 liutoho 2010 r. № 121-r. Retrieved from http: zakon4.rada.gov.ua/laws/show/1158-2007-\% D0\%BF [in Ukrainian]

4. Derzhavni budivelni normy «Mistobuduvannia, planuvannia ta zabudova miskykh i silskykh poselen» DBN-360-92* (1992) [State building norms "Urban planning, planning and construction of urban and rural settlements" DBN-360-92 *]. Kyiv: Derzhbud Ukrainy. 92 s. [in Ukrainian]

5. Krasnova N.M., Velikando A.I., Voronkov D.O. (2007) Tipyi i formyi selskih poseleniy $\mathrm{v}$ Ukraine: uchebno-metodologicheskoe posobie [Types and forms of rural settlements in Ukraine: educational-methodological manual] Lvov: Znanie. 76 s. [in Russian]

6. Nosik V. V. (2006) Pravo vlasnosti na zemliu Ukrainskoho narodu : monohrafiia [Land ownership of the Ukrainian people: monograph] Kyiv, Yurinkom Inter. $520 \mathrm{~s}$. [in Ukrainian]

7. Ofitsiinyi veb-portal Verkhovnoi Rady Ukrainy (2020) [Official web portal of the Verkhovna Rada of Ukraine]. Retrieved from http: http://w1.c1. rada.gov.ua/pls/zweb2/webproc4_1?pf351 [in Ukrainian]

8. Ofitsiinyi veb-sait Voskresenskoi selyshchnoi rady (2020) [Official website of Voskresenska village council]. Retrieved from http: https:// voskresenska.rada.today

9. Pro dobrovilne obiednannia terytorialnykh hromad (2020) Zakon Ukrainy 157-VIII vid 14.05.2020 [About voluntary association of territorial communities] Vidomosti Verkhovnoi Rady. № 13. st. 91 [in Ukrainian]

10. Pro okhoronu zemel (2017) Zakon Ukrainy № 962-IV vid 18.12.2017 [About land protection] Vidomosti Verkhovnoi Rady Ukrainy. № 39. st. 349 [in Ukrainian]

11. Pro provedennia inventaryzatsii zemel silskohospodarskoho pryznachennia derzhavnoi vlasnosti (2018) Nakaz derzhavnoi sluzhby z pytan heodezii, kartohrafii ta kadastru № 45 vid 15.03.2018 roku [About carrying out inventory of agricultural lands of the state property] Retrieved from http: search. ligazakon.ua/1_doc2.nsf/link1/FN041353.html [in Ukrainian] 
12. Pro rehuliuvannia mistobudivnoi diialnosti (2020) Zakon Ukrainy № 3038-VI vid 07.06.2020 [About regulation of town-planning activity] Vidomosti Verkhovnoi Rady Ukrainy. № 34. st. 343 [in Ukrainian]

13. Pro vnesennia zmin do deiakykh postanov Kabinetu Ministriv Ukrainy (2016) Postanova KMU № 482 vid 22 lypnia 2016 r. [On amendments to some resolutions of the Cabinet of Ministers of Ukraine] Retrieved from http: zakon.rada.gov.ua/laws/show/482-2016-\%D0\%BF\#Text [in Ukrainian]

14. Pro vnesennia zmin do deiakykh zakonodavchykh aktiv Ukrainy shchodo rozmezhuvannia zemel derzhavnoi ta komunalnoi vlasnosti (2013) Zakon Ukrainy № 5245-VI vid 16.06.2013 [About modification of some legislative acts of Ukraine concerning delimitation of the lands of the state and municipal property] Vidomosti Verkhovnoi Rady. № 36. st. 472 [in Ukrainian]

15. Pro zemleustrii (2020) Zakon Ukrainy № 858-IV vid 16.01.2020 [About land management] Vidomosti Verkhovnoi Rady Ukrainy. № 36. st. 282 [in Ukrainian]

16. Pytannia peredachi zemelnykh dilianok silskohospodarskoho pryznachennia derzhavnoi vlasnosti u komunalnu vlasnist obiednanykh terytorialnykh hromad (2018) Rozporiadzhennia KMU vid 31.01.2018 roku № 60-r [Issues of transfer of state-owned agricultural land to communal ownership of united territorial communities] Retrieved from http: https://www.kmu.gov.ua/ npas/pitannya-peredachi-1 [in Ukrainian]

17. Yemelianov V.M., Ibrahimova A.A. (2016) Sotsialno-ekonomichnyi analiz Novobuzkoho raionu Mykolaivskoi oblasti ta perspektyvy formuvannia spromozhnykh terytorialnykh hromad $\mathrm{v}$ tsomu raioni [Socio-economic analysis of the Novobuzhsky area of the Nikolaev area and prospects of formation of capable territorial communities in this area] Naukovi pratsi [Chornomorskoho derzhavnoho universytetu imeni Petra Mohyly kompleksu Kyievo-Mohylianska akademiia]. Seriia: Derzhavne upravlinnia. T. 281. Vyp. 269. S. 24-39 [in Ukrainian]

18. Yevtushenko O. N. (2009) Problemy detsentralizatsii derzhavnoi vlady i mistseve samovriaduvannia $\mathrm{v}$ Ukraini [Problems of decentralization of state power and local self-government in Ukraine] Hileia: naukovyi visnyk. Zbirnyk naukovykh prats. № 29. S. 22-33 [in Ukrainian]

19. Zemelnyi Kodeks Ukrainy (2020) Zakon Ukrainy № 2768-III vid 07.06.2020 [Land Code of Ukraine] Vidomosti Verkhovnoi Rady Ukrainy. № 3-4. st. 27 [in Ukrainian] 
20. Malynovska, N., Shtyrov, O., \& Holovashchenko, N. (2020). Normatyvna hroshova otsinka zemel yak mekhanizm stymuliuvannia rozvytku hromad [Normative monetary valuation of land as a mechanism for stimulating community development]. Публічне управління та регіональний розвиток, (10), 1164-1197. https://doi.org/10.34132/pard2020.10.09 [in Ukrainian]

\section{Відомості про авторів / Information about the Authors}

Андріяш Вікторія Іванівна: Інститут державного управління, Чорноморський національний університет імені Петра Могили вул. 68 десантників 10, Миколаїв, 54003, Україна.

Victoria Andriyash: Institute of Public Administration Black Sea National University of Petro Mohyla: 68 Desantnykiv str. 10, Mykolaiv, 54003, Ukraine.

\section{ORCID. ORG/ 0000-0001-5294-7456}

\section{E-mail: andriyash_v2017@ukr.net}

Свтушенко Олександр Никифорович: Чорноморський національний університет імені Петра Могили: вул. 68 десантників 10, м. Миколаїв, 54003, Україна.

Alexander Evtushenko: Institute of Public Administration Black Sea National University of Petro Mohyla: 68 Desantnykiv str. 10, Mykolaiv, 54003, Ukraine.

\section{ORCID.ORG./ 0000-0002-5161-3312}

\section{E-mail: alnievt@ukr.net}

Лушагіна Тетяна Вікторівна: Чорноморський національний університет імені Петра Могили: вул. 68 десантників 10, м. Миколаїв, 54003, Україна. 
Tetyana Lushahina: Black Sea National University of Petro Mohyla: 68 Desantnykiv str. 10, Mykolaiv, 54003, Ukraine.

ORCID.ORG./ 0000-0001-8599-2923

\section{E-mail: t.lushagina@gmail.com}

Лінінська Оксана Анатоліївна: Воскресенська селищна рада, Вітовського району Миколаївської області: вул. Соборна, буд. 86, смт. Воскресенське, 57210, Україна.

Oksana Lininska: Head of the Department of Land Voskresenska village council, Mykolaiv region57210, Ukraine.

ORCID.ORG./ 0000-0002-6172-7987 